\title{
PENGARUH METODE PEMBELAJARAN DAN GAYA BELAJAR TERHADAP HASIL BELAJAR HADITS SISWA KELAS VII MTS. PESANTREN AR-RAUDHATUL HASANAH MEDAN
}

\author{
Khairul Anwar ${ }^{1}$, Harun Sitompul ${ }^{2}$ \\ Pascasarjana Universitas Negeri Medan ${ }^{1,2}$ \\ khairul_anwar@yahoo.com ${ }^{1}$
}

\begin{abstract}
Abstrak: Tujuan penelitian ini adalah untuk mengetahui apakah hasil belajar siswa yang diajarkan dengan metode pembelajaran hypnoteaching lebih tinggi dari siswa yang diajarkan dengan metode pembelajaran ekspositori, hasil belajar Hadits siswa yang memiliki gaya belajar visual lebih tinggi dari siswa yang memiliki gaya belajar kinestetik, dan interaksi antara metode pembelajaran dan gaya belajar dalam memberikan pengaruh terhadap hasil belajar Hadits. Metode penelitian menggunakan quasi eksperimen dengan desain penelitian faktorial $2 \times 2$. Teknik analisis data menggunakan ANAVA dua jalur pada taraf signifikan $\alpha=0,05$. Temuan penelitian menunjukkan : (1) hasil belajar Hadits siswa yang diajar dengan metode pembelajaran hypnoteaching lebih tinggi dibandingkan siswa yang diajar dengan metode pembelajaran ekspositori, (2) hasil belajar Hadits siswa yang memiliki gaya belajar visual lebih tinggi dibandingkan dengan hasil belajar Hadits siswa yang memiliki gaya belajar kinestetik, dan (3) Terdapat interaksi antara metode pembelajaran dan gaya belajar dalam mempengaruhi hasil belajar Hadits siswa. Siswa yang memiliki gaya belajar visual memiliki hasil belajar lebih tinggi jika dibandingkan dengan siswa yang memiliki gaya belajar kinestetik yang di ajar dengan metode pembelajaran hypnoteaching.
\end{abstract}

Kata Kunci: metode pembelajaran dan gaya belajar terhadap hasil belajar hadits

Abstract: The purpose of this study was to determine whether the learning outcomes of students who are taught by the teaching methods hypnoteaching higher than students taught with methods expository, learning outcomes Hadith students who have a visual learning style higher than students who have a kinesthetic learning style, and interaction between teaching methods and learning styles in giving effect to the learning outcomes Hadith. The research method using a quasi-experimental design with a $2 \times 2$ factorial study. Data were analyzed using ANOVA two lanes on the significant level $\alpha=0.05$. The findings show: (1) the learning outcomes Hadith students who are taught by the teaching methods hypnoteaching higher than students taught with methods expository, (2) learning outcomes Hadith students who have a visual learning style more than in the learning outcomes Hadith students who have kinesthetic learning style, and (3) There is an interaction between teaching methods and learning styles in influencing student learning outcomes Hadith. Students who have a visual learning style education outcomes are higher when compared with students who have a learning style that kinesthetic learning methods in teaching with hypnoteaching.

Keywords: teaching methods and learning styles on learning outcomes hadith

\section{PENDAHULUAN}

Pesantren merupakan salah satu lembaga pendidikan Islam juga mengintegrasikan nilai-nilai dan karakter dalam kehidupan peserta didik, tidak hanya dalam satuan pendidikan, tapi juga dalam keseharian peserta didik atau santri yang hidup dalam sistem asrama 24 jam. Sebagaimana yang dilakukan oleh Pesantren Ar-Raudhatul Hasanah Medan. Para santri tinggal di asrama selama 24 jam, dengan menciptakan miliu atau lingkungan yang diarahkan untuk membentuk karakter para santri, sehingga ada slogan di pesantren tersebut, "Apa yang dilihat, didengar dan dirasakan adalah untuk pendidikan". Saat ini banyak sekolah agama yang sudah bermetamorfosis menjadi sekolah-sekolah unggulan, yang meskipun membuka kesempatan kepada siswanya untuk mampu menguasai teknologi dan ilmu-ilmu popular, tapi masih tetap mengedepankan pembinaan keyakinan dan penghayatan pada agama, dan 
sudah banyak alumnusnya yang berkecimpung dalam masyarakat.

Hypnoteaching merupakan metode pembelajaran yang memakai sugesti-sugesti positif untuk mencapai alam sadar peserta didik. C.George B. menjelaskan bahwa sebenarnya suara manusia aka selalu memiliki kebermaknaan yang lebih besar dan intrinsik dibandingkan dengan alat apa pun yang disukai dalam proses pembelajaran (2008:65). Dengan kata lain, secanggih atau sebaik apa pun suatu media atau alat bantu pembelajaran, masih tidak jauh lebih baik bila dibandingkan dengan suara atau kata-kata yang diucapkan gurunya.

Untuk memperoleh hasil belajar yang maksimal suatu kegiatan pembelajaran juga dipengaruhi oleh kemampuan guru dalam mengenal dan memahami karakteristik peserta didik. Dick \& Carey (2005:6) mengatakan bahwa seorang guru hendaknya mampu untuk mengenal dan mengetahui karakteristik peserta didik, sebab pemahaman yang baik terhadap karakteristik peserta didik akan sangat berpengaruh terhadap keberhasilan proses belajar peserta didik. Karena jika seorang guru dapat mengetahui karakteristik peserta didiknya, maka selanjutnya guru dapat menyesuaikannya dengan metode pembelajaran yang hendak digunakan.

Karakteristik peserta didik yang dimaksudkan dalam penelitian ini adalah gaya belajar peserta didik, yakni cara yang lebih disukai peserta didik dalam belajar, memproses dan mengerti suatu informasi. Karena hasil riset menunjukkan bahwa peserta didik yang belajar dengan menggunakan gaya belajar mereka yang dominan, saat mengerjakan tes akan mencapai nilai yang jauh lebih tinggi dibandingkan bila mereka belajar dengan cara yang tidak sejalan dengan gaya belajar mereka (Gunawan, 2004 : 139).

Menurut Munif Chatif (2009:35) apabila gaya mengajar guru sesuai dengan gaya belajar peserta didik, semua pelajaran akan terasa sangat mudah dan menyenangkan. Guru juga senang karena memiliki peserta didik yang cerdas dan berpotensi untuk sukses pada jenis kecerdasan yang dimilikinya. Berdasarkan penelitian yang dilakukan oleh Dr. Howard Earl Gardner (dalam Chatif, 2009:20) ternyata gaya belajar peserta didik tercermin dari kecendrungan kecerdasan yang dimiliki oleh peserta didik tersebut.

Menurut Gunawan (2004 : 142) jenis gaya belajar berdasarkan preferensi sensori adalah visual, auditori dan kinestetik, yang dikenal dengan modalitas V-A-K. Walaupun masing-masing dari kita belajar dengan menggunakan ketiga modalitas ini pada tahapan tertentu, kebanyakan orang lebih cenderung pada salah satu di antara ketiganya. Bila karakteristik masing-masing gaya belajar peserta didik dikaitkan dengan pembelajaran Hadits dan metode hypnoteaching yang salah satu unsur hypnosis dalam pembelajaran adalah peraga atau mengeluarkan ekspresi diri, maka yang menjadi bahasan adalah gaya belajar visual dan gaya belajar kinestetik.

Belajar adalah proses orang memperoleh berbagai kecakapan, keterampilan, dan sikap. Belajar mulai masih kecil ketika bayi memperoleh sejumlah kecil keterampilan yang sederhana, seperti memegang botol susu atau mengenal ibunya. Selama masa kanak-kanak dan masa remaja, diperoleh sejumlah sikap, nilai, dan keterampilan hubungan sosial, demikian pula diperoleh kecapakan dalam berbagai mata ajaran sekolah. Dalam usia dewasa, orang diharapkan telah mahir mengerjakan tugas-tugas pekerjaan tertentu dan keterampilan-keterampilan fungsional yang lain.

Menurut teori kognitif, belajar adalah perubahan persepsi dan pemahaman. Perubahan persepsi dan pemahaman tidak selalu berbentuk perubahan perilaku yang dapat diamati. Teori kognitif mulai berkembang dengan lahirnya teori belajar Gestalt. Peletak dasar teori gestalt adalah Max Wertheimer (1880-1943) yang meneliti tentang pengamatan dan problem solving. Sumbangannya diikuti oleh Kurt Koffka (1886-1941) yang menguraikan secara terperinci tentang hukum-hukum pengamatan, kemudian Wolfgang Kohler (1887-1967) yang meneliti tentang insight pada simpanse. Kaum gestaltis berpendapat bahwa pengalaman itu berstuktur yang terbentuk dalam suatu keseluruhan. Menurut pandangan gestaltis, semua kegiatan belajar menggunakan pemahaman terhadap hubungan hubungan, terutama hubungan antara bagian dan keseluruhan. Intinya, menurut mereka, tingkat kejelasan dan keberartian dari apa yang diamati dalam situasi belajar adalah lebih meningkatkan kemampuan belajar seseorang dari pada dengan hukuman dan ganjaran. Ciri-ciri dari teori belajar kognitif, adalah dalam situasi belajar, seseorang terlibat langsung dalam situasi itu dan memperoleh insight untuk pemecahan masalah, tingkah laku seseorang lebih 
bergantung kepada pemahaman terhadap hubungan - hubungan yang ada didalam suatu situasi, memberi tekanan pada organisasi pengamatan di dalam lingkungan, motivasi dan reward berperan penting, pertumbuhan intelektuan berupa kualitatif, perkembangan kognitif bergantung kepada akomodasi, anak harus berperan secara aktif di dalam belajar di kelas, anak mengembangkan kemampuan berpikirnya menurut tahap yang teratur.

Hasil belajar diartikan sebagai tingkat penguasaan yang dicapai oleh peserta didik dalam mengikuti proses pembelajaran sesuai dengan program pendidikan yang ditetapkan. Gagne (1979) mengatakan bahwa perolehan belajar atau hasil belajar merupakan kapasitas teratur dari perubahan individu yang diinginkan berdasarkan ciri-ciri atau variabel-variabel bawaannya melalui perlakuan pengajaran tertentu. Dalam pengertian ini, hasil belajar merupakan hasil kegiatan dari belajar yang diperoleh peserta didik dari proses belajar.

Reigeluth (1983: 393) mengemukakan bahwa hasil belajar merupakan salah satu aspek pengajaran yang dibagi atas tiga jenis yaitu : (1) keefektifan pengajaran yang diukur dengan tingkat pencapaian si belajar pada tujuan atau isi bidang studi yang telah ditetapkan, (2) efisiensi pengajaran diukur dengan rasio antara keefektifan dan jumlah waktu yang dipakai si belajar dan atau jumlah biaya pengajaran yang digunakan, dan (3) daya tarik pengajaran yang diukur dengan mengamati kecendrungan peserta didik untuk tetap belajar.

Sementara Joyce dan Weil (1986: 10) mengacukan hasil belajar atau pengajaran langsung sebagai instructional effects, dan pengajaran yang terbentuk secara kumulatif disebutnya sebagai nurturant effects. Hasil belajar diukur setelah peserta didik mengikuti semua kegiatan pembelajaran dengan tes hasil belajar. Selain itu, Reigulth dan Merrill mengemukakan bahwa pengukuran keefektifan pengajaran harus selalu dikaitkan dengan pencapaian tujuan pengajaran. Tiga indikator lainnya dalam kaitannya dengan pencapaian tujuan yaitu : (1) kesesuaian dengan prosedur, (2) kuantitas unjuk kerja, dan (3) kualitas hasil akhir.

Menurut Bloom mengklasifikasikan hasil belajar menjadi tiga, yaitu : (1) kognitif, (2) afektif, (3) psikomotorik. Selanjutnya, Bloom mengklasifikasikan lebih lanjut ranah kognitif menjadi enam, yaitu: (1) pengetahuan, (2) pemahaman, (3) penerapan, (4) analisis, (5) sintesis, (6) penilaian dalam Dimyati dan Mudjiono (2009:11) . Adapun Gagne mengklasifikasikan hasil belajar menjadi lima, yaitu: (1) keterampilan intelektual, yang ditujukan oleh peserta didik tentang operasioperasi intelektual yang dapat dilakukan, (2) metode kognitif, merupakan suatu proses control (3) informasi verbal, pengetahuan yang disajikan dalam bentuk proposisi (gagasan) dan bersifat statis, (4) keterampilan motorik, kemampuan yang meliputi kegiatan fisik, penggabungan motorik dengan keterampilan intelektual, (5) sikap, merupakan pembawaan yang dapat dipelajari dan dapat memengaruhi prilaku seseorang terhadap benda-benda, kejadian-kejadian, atau makhluk hidup lainnya, dalam Dimyati dan Mudjiono (2009:26) .

Kata 'metode' berasal dari bahasa Yunani methodos yang berarti "cara atau jalan". Didalam bahasa inggris disebut method dan bahasa arab menterjemahkannya dengan thariqoh dan manhaj. Didalam bahasa Indonesia kata tersebut mengandung arti cara yang teratur dan berpikir baik-baik untuk mencapai maksud atau cara kerja yang sistematis untuk memudahkan pelaksanaan suatu kegiatan guna mencapai tujuan yang telah ditentukan. Jadi metode pendidikan adalah cara yang teratur dan berpikir baik-baik yang digunakan untuk memberikan pelajaran kepada peserta didik. (Erwati Aziz, 2003:79)

Metode juga berarti cara atau jalan yang ditempuh atau dilalui untuk mencapai tujuan tertentu dan metode mengajar adalah jalan yang harus dilalui untuk mengajar anak didik supaya dapat mencapai tujuan belajar mengajar. (Ramayulis,2001:2)

Sagala, S. (2003:169) mengemukakan, metode pembelajaran adalah cara yang digunakan guru dalam mengorganisasikan kelas pada umumnya atau dalam menyajikan bahan pelajaran pada khususnya. Surakhmad, W. (1979:75) mengemukakan metode adalah cara yang di dalam fungsinya merupakan alat untuk mencapai suatu tujuan

Hatimah, I. (2000:10) metode pembelajaran tidak hanya berfungsi sebagai cara untuk menyampaikan materi saja, melainkan berfungsi juga untuk pemberian dorongan, pengungkap tumbuhnya minat belajar, penyampaian bahan belajar, pencipta iklim belajar yang kondusif, tenaga untuk melahirkan kreativitas, pendorong untuk penilaian diri dalam proses dan hasil belajar, 
dan pendorong dalam melengkapi kelemahan hasil belajar.

Menurut Novian Triwidia Jaya (2010:41), hypnoteaching merupakan perpaduan pengajaran yang melibatkan pikiran sadar dan bawah sadar. Hypnoteaching ini merupakan metode pembelajaran yang kreatif, unik, sekaligus imajinatif. Sebelum pelaksanaan pembelajaran, para anak didik sudah dikondisikan untuk belajar. Dengan demikian, anak didik mengikuti pembelajaran dalam kondisi segar dan siap untuk menerima materi pelajaran. Untuk mempersiapkan hal-hal tersebut, tentu guru sendiri juga dituntut untuk stabil secara psikologis, maupun secara psikis. Dengan begitu, guru pun mempunyai kesiapan yang penuh dalam mengajar para anak didiknya.

Sementara itu, menurut Muhammad Noer (2010:21), di dalam hypnoteaching guru bertindak sebagai penghipnotis, sedangkan anak didik berperan sebagai "suyet" atau orang yang dihipnotis. Dalam pembelajaran, sebenarnya guru tidak perlu menidurkan anak didiknya ketika memberikan sugesti. Guru cukup menggunakan bahasa yang persuasif sebagai alat komunikasi yang sesuai dengan harapan anak didik. Hal yang harus diingat adalah guru harus berusaha menyampaikan kepada anak didik dengan bahasa yang mudah dipahami oleh anak didik. Sebab, sangat tidak mungkin hipnosis bisa berjalan secara efektif jika "suyet" tidak paham akan maksud dari penghipnotis.

Dari penjelasan sebelumnya, dapat diketahui bahwa metode hypnoteaching hanya bermain pada kekuatan pikiran alam bawah sadar. Melalui penguasaan hypnoteaching, para guru akan menjadi lebih lain, dapat dipahami bahwa hypnoteaching adalah pengembangan pada metode pembelajaran. Melalui hypnoteaching, guru dapat melakukan pendekatan konseptual yang baru terhadap anak didiknya. Selain itu, metode ini juga memberikan "terapi penyembuhan" pada anak didik yang mempunyai permasalahan belajar maupun psikis

Menurut Muhammad Noer (2010:45),

dalam hypnoteaching ada beberapa langkah yang perlu dilakukan oleh guru. Langkahlangkah tersebut sebagai berikut.

a. Niat dan motivasi dalam diri.

Kesuksesan seseorang sangat bergantung pada niatnya untuk senantiasa berusaha dan berkerja keras dalam mencapai kesuksesan yang ingin diraihnya.

b. Pacing, artinya menyamakan posisi, gerak tubuh, bahasa, serta gelombang otak dengan orang lain. Dalam hal ini orang lain tersebut adalah peserta didik. Prinsip dalam langkah ini adalah manusia cenderung atau lebih suka berkumpul, berinteraksi dengan sejenisnya, atau banyak kesamaan. Dengan demikian, secara alami dan naluriah, setiap orang pasti akan merasa nyaman dan senang untuk berkumpul dengan orang lain yang mempunyai kesamaan dengannya. Adapun caracara melakukan pacing kepada peserta didik sebagai berikut.

1) Langkah awal bagi guru adalah membayangkan dirinya menjadi sosok yang seusia dengan para peserta didiknya. Hal tersebut dapat dilakukan melalui aktifitas dan merasakan hal-hal yang dialami oleh peserta didik pada masa sekarang. Bukan ketika guru tersebut masih bersekolah dulu.

2) Menggunakan bahasa yang sesuai dengan bahasa yang disukai oleh para peserta didik. Bahkan bila perlu seorang guru bisa menggunakan "bahasa gaul" yang tengah marak dipakai oleh para peserta didiknya.

3) Melakukan gerakan-gerakan dan mimik wajah yang sesuai dengan tema bahasan guru.

4) Mengaitkan tema pelajaran yang sedang dibahas dengan tema-tema yang sedang marak dibahas oleh peserta didik.

c. Leading, berarti memimpin atau mengarahkan. Setelah guru melakukan pacing, peserta didik akan merasa nyaman dengan suasana pembelajaran yang berlangsung. Ketika itulah hamper setiap apa pun yang diucapkan oleh guru atau ditugaskan kepada peserta didik, peserta didik akan melakukannya dengan suka rela dan senang hati.

d. Menggunakan kata-kata positif. Langkah ini merupakan langkah pendukung dalam melakukan pacing dan leading. Penggunaan kata-kata positif ini sesuai dengan cara kerja pikiran bawah sadar mereka yang tidak 
mau menerima kata-kata negatif. Katakata yang diberikan oleh pendidik entah langsung maupun tidak langsung sangat mempengaruhi kondisi psikis peserta didik. Misalnya, ketika peserta didik di kelas ramai dan gaduh, guru jangan mengatakan "jangan ramai", tetapi diganti dengan mengatakan "mohon tenang".

e. Memberikan pujian. Salah satu hal penting yang harus diingat oleh guru adalah adanya reweard and punishment dalam proses pembelajaran. Pujian adalah reward peningkatan harga diri seseorang. Pujian ini merupakan salah satu cara untuk membentuk konsep diri seseorang. Sementara itu, punishment merupakan hukuman atau peringatan yang diberikan guru ketika peserta didik melakukan suatu tindakan yang kurang sesuai.

f. Modeling, merupakan proses pemberian teladan atau contoh melalui ucapan dan perilaku yang konsisten. Hal ini merupakan sesuatu yang sangat penting dan menjadi salah satu kunci berhasil atau tidaknya hypnoteaching. Setelah peserta didik merasa nyaman dengan guru dan suasana pembelajaran, diperlukan pula kepercayaan peserta didik pada guru yang dimantapkan melalui perilaku dan ucapan yang konsisten dari guru. Hal ini akan membuat guru menjadi sosok yang bisa dipercaya di mata peserta didik.

g. Untuk mendukung serta memaksimalkan sebuah pembelajaran hypnoteaching, sebaiknya guru juga menguasai materi pelajaran secara komprehensif. Hal ini dapat dilakukan dengan melibatkan peserta didik secara aktif dalam proses pembelajaran. Selain itu, guru juga mengupayakan untuk melakukan interaksi informal dengan peserta didik.

Dalam proses pembelajaran dengan metode ceramah harus peka terhadap respon peserta didik. Skiner dalam Driscoll (1994 : 30) menjelaskan bahwa diskripsi hubungan antara stimulan dan respon tidaklah sesederhana yang diperkirakan, melainkan stimulan yang diberikan berinteraksi satu dengan lainnya, dan interaksi ini artinya mempengaruhi respon yang diberikan juga menghasilkan berbagai konsekwensi yang akan mempengaruhi tingkah laku peserta didik. Untuk menciptakan terjadinyan interaksi, menarik perhatian peserta didik dan melatih keterampilan peserta didik, metode ceramah biasanya dikombinasikan dengan metode tanya jawab dan pemberian tugas. Resitasi atau tugas dapat pula dikerjakan di luar rumah ataupun di dalam laboratorium. Pasaribu mengemukanan bahwa metode resitasi mempunyai tiga fase, yaitu : a) guru memberi tugas, b) peserta didik melaksakan tugas, dan c) peserta didik mempertanggung-jawabkan pada guru apa yang telah dipelajari (Sutomo, 2003: 45).

Nasution (2005:94) mendefenisikan gaya belajar sebagai suatu cara yang konsisten yang dilakukan oleh seorang peserta didik dalam menangkap stimulus atau informasi, cara mengingat, berpikir, dan membacakan masalah. Setiap orang memiliki gaya belajar yang berbeda. Selain berbeda dalam tingkat kecakapan, memecahkan masalah, taraf kecerdasan atau kemampuan berpikir kreatif, juga berbeda dalam memperoleh, menyimpan dan mengolah informasi.

Berbagai ahli mengelompokkan jenis gaya belajar dengan masing-masing pendekatannya. Walaupun banyak pendekatan dalam hal gaya belajar, yang penting adalah bagaimana pengetahuan mengenai gaya belajar itu dapat digunakan untuk membantu guru memaksimalkan proses pembelajaran. Dari berbagai pendekatan yang ada menurut Gunawan (2004: 142) yang paling populer dan sering digunakan saat ini ada 3 (tiga) yaitu : 1) pendekatan berdasarkan preferensi sensori, 2) profil kecerdasan dan 3) preferensi kognitif.

Pendekatan berdasarkan preferensi sensori mencakup gaya belajar visual, auditorial dan kinestetik. Dan dalam penelitian ini gaya belajar yang dimaksud digolongkan mnejadi 2 (dua) kategori, yakni gaya belajar kinestetik dan gaya belajar visual. DePorter \& Hernacki (2003:113) mengatakan bahwa ketiganya adalah merupakan modalitas belajar. Dimana visual adalah belajar dengan cara melihat, auditorial belajar dengan cara mendengar sedangkan kinestetik adalah belajar dengan cara bergerak, bekerja dan menyentuh.

Grinder and Bandler (1989: 70) mengatakan bahwa kebanyakan orang memiliki akses ketiga modalitas (visual, auditorial dan kinestetik) dan hampir semua orang cenderung pada salah satu modalitas belajar yang berperan sebagai saringan untuk pembelajaran, pemrosesan dan komunikasi. Sependapat 
dengan hal itu Rose \& Nicholl (1977: 60) mengatakan bahwa dalam kenyataan kita semua memiliki ketiga gaya belajar (visual, auditorial dan kinestetik) hanya saja biasanya satu gaya yang mendominasi. Sedangkan Dawna Markova (2007: 15) mengatakan orang tidak cenderung pada satu modalitas tertentu yang memberi mereka bakat dan kekurangan alami tertentu.

Sehubungan dengan uraian penegasan tentang gaya belajar seperti pada pembatasan masalah dan uraian di atas bahwa peserta didik yang memiliki dominan gaya belajar kinestetik adalah dikategorikan memiliki gaya belajar kinestetik, sedangkan peserta didik yang memiliki dominan gaya belajar visual dikategorikan memiliki gaya belajar visual. Sedangkan instrumen gaya belajar yang digunakan adalah berupa angket. Angket ini merujuk pada buku "Quantum Teaching" oleh De Porter dan Hernacki (2003).

Meier (2005:92) menyebutkan gaya belajar kinestetik dengan istilah somatis, yang diartikan dari bahasa Yunani berarti tubuh. Belajar somatis berarti belajar dengan indera peraba, kinestetik/praktis, melibatkan fisik dan menggunakan serta menggerakkan tubuh sewaktu belajar. Biasanya peserta didik yang memiliki gaya belajar ini mempunyai sifat hiperaktif. Hal itu wajar-wajar saja, sehat dan normal. Bukan suatu penyakit seperti yang terjadi di dunia Barat yang mencap anak hiperaktif sebagai pengidap kelainan sehingga harus diberi obat.

De Porter \& Hernacki (2003:114) menyatakan bahwa pelajar kinestetik lebih baik dalam aktivitas bergerak dan interaksi kelompok. Dengan suatu ilustrasi misalnya seseorang membeli sebuah alat panggangan yang terdiri dari 35 bagian yang terpisah-pisah dan dilengkapi buku petunjuk setebal 12 halaman yang dapat membantu merangkai alat tersebut. Maka jika seseorang mulai bekerja dengan bagian-bagian tersebut secara fisik maka orang tersebut adalah seorang pelajar yang mempunyai gaya belajar kinestetik.

Sejalan dengan itu Gunawan (2004: 149) menyatakan bahwa orang kinestetik sangat peka terhadap perasaan atau emosi dan pada sensasi sentuhan dan gerakan. Bila diminta untuk menuliskan suatu kata, orang ini akan "merasakan" dulu kata tersebut baru setelah itu, menuliskan kata tersebut. Orang kinestetik akan belajar maksimal dalam suatu kondisi dimana banyak keterlibatan fisik dan gerakan.
Ciri-ciri fisiologis seorang pelajar yang memiliki gaya belajar kinestetik adalah : 1) gerakan bola mata kearah bawah, 2) pernafasan perut dan dalam, 3) suara cenderung berat, 4) menggunakan gerakan/bahasa tubuh, 5) mengakses informasi sambil melihat ke bawah. Sedangkan ciri bahasa yang sering digunakan pelajar yang memiliki gaya belajar kinestetik adalah : 1) ini rasanya kurang pas, 2) saya ingin anda merasakan hal ini, 3) ini rasanya masih kurang jelas.

Menurut De Porter et al (2001:85) bahwa gaya belajar kinestetik adalah modalitas mengakses segala jenis gerak dan emosi yang diciptakan maupun yang diingat. Gerakan koordinasi, irama, tanggapan emosional dan kebanyakan kegiatan fisik yang menonjol. Pelajar-pelajar kinestetik menyukai proyek terapan, lelucon pendek dan lucu dapat membantu para pelajar kinestetik. Mereka juga suka belajar melalui gerak dan paling baik menghafal informasi dengan mengasosiasikan gerakan dengan setiap fakta.

Menurut Meier (2005:96-97) belajar visual lebih mudah belajar jika dapat "melihat" apa yang sedang dibicarakan seseorang penceramah atau sebuah buku atau program komputer. Pelajar visual belajar paling baik jika mereka dapat melihat contoh dari dunia nyata, diagram, peta gagasan, ikon, gambar, dan gambaran dari segala macam hal ketika mereka sedang belajar. De Porter et al (2000:85) mendefenisikan bahwa orang visual mengakses citra visual, yang diciptakan maupun yang diingat. Warna, hubungan ruang, potret mental, dan gambar lebih menonjol. Sehingga tidak jarang orang yang memiliki gaya belajar ini rapi dalam penampilannya.

Sejalan dengan itu Gunawan (2004:149) mengatakan bahwa orang visual akan sangat mudah melihat atau membayangkan apa yang dibicarakan. Mereka sering melihat gambar yang berhubungan dengan kata atau perasaan dan akan mengerti suatu informasi bila melihat kejadian, melihat informasi itu tertulis atau dalam bentuk gambar. Selanjutnya Gunawan menambahkan ciri-ciri fisiologi orang yang memiliki gaya belajar visual adalah : gerakan bola mata kearah atas, bernafas dengan pernapasan dada, nada suara tinggi, nafas pendek/dangkal, mengakses informasi dengan melihat ke atas, dan tempo bicara cepat.

De Porter \& Hernacki (2003:14) menyebutkan bahwa orang visual lebih suka 
membaca makalah dan memperhatikan ilustrasi yang ditempelkan pembicara di papan tulis. Mereka juga dapat membuat catatan-catatan yang sangat baik. Berikut indikator-indikator orang visual : (1) rapi dan teratur, (2) berbicara dengan cepat, (3) perencana dan pengatur jangka panjang, (4) teliti terhadap detail, (5) mementingkan penampilan, (6) baik dalam hal pakaian maupun persentasi, (7) pengeja yang baik dan dapat melihat kata-kata yang sebenarnya dalam pikiran mereka, (8) mengingat apa yang dilihat dari pada apa yang didengar, (9) biasanya tidak terganggu oleh keributan, (10) mempunyai masalah mengingat instruksi verbal, kecuali jika ditulis, (11) pembaca cepat dan tekun, (12) lebih suka membaca dari pada dibacakan, (13) mencoretcoret tanpa arti selama berbicara di telepon atau dalam rapat, (14) sering lupa menyampaikan pesan verbal kepada orang lain, (15) sering menjawab pertanyaan dengan jawaban singkat, (16) lebih suka seni dari pada musik.

Berdasarkan kerangka berfikir yang telah dikemukakan di atas, hipotesis penelitian ini dapat dirumuskan sebagai berikut: (1) Hasil belajar Hadits peserta didik yang dibelajarkan dengan menggunakan metode pembelajan hypnoteaching lebih tinggi dari pada peserta didik yang dibelajarkan dengan metode pembelajaran ekspositori; (2) Hasil belajar Hadits peserta didik yang memiliki gaya belajar visual lebih tinggi dari pada peserta didik yang memiliki gaya belajar kinestetik; (3) Terdapat interaksi antara metode pembelajaran dan gaya belajar peserta didik terhadap hasil belajar mata pelajaran Hadits.

\section{METODE}

Penelitian dilaksanakan pada semester II Kelas VII di Madrasah Tsanawiyah Swasta Pesantren Ar-Raudhatul Hasanah Medan. Pemilihan tempat ini didasarkan pada pertimbangan bahwa di sekolah ini belum pernah dilakukan penelitian perlakuan serupa.

Populasi dalam penelitian ini adalah seluruh santri kelas VII Madrasah Tsanawiyah Swasta Pesantren Ar-Raudhatul Hasanah yang berjumlah 373 santri orang terdiri dari 10 (sepuluh) kelas. Sampel merupakan sebagian dari populasi yang dipilih secara representative, artinya segala karakteristik populasi tercermin dari sampel yang diambil (Sudjana, 1992:6). Mengingat penelitian ini melakukan perlakuan maka jumlah populasi 383 orang ini tidak diambil secara keseluruhan, pengambilan sampel ditetapkan dengan teknik cluster random sampling, selanjutnya dengan menggunakan teknik tersebut ditentukan 2 (dua) kelas sampel sebagai kelompok eksperimen yaitu 1 kelas menjadi kelas perlakuan metode pembelajaran hypnoteaching dan 1 kelas yang menjadi kelas perlakuan metode pembelajaran ekspositori.

Metode penelitian yang digunakan dalam penelitian ini adalah quasi eksperimen. Metode ini digunakan karena kelas yang dipakai untuk perlakuan merupakan kelas yang sudah terbentuk sebelumnya atau tanpa mengubah situasi dan kondisi kelas yang sudah terbentuk.

Dalam penelitian ini, peneliti membuat metode pembelajaran yang berbeda dalam kelas yang berbeda, yaitu satu kelas dengan metode pembelajaran hypnoteaching, dan satu kelas dengan metode pembelajaran ekspositori. Setelah selesai melakukan penelitian ini diharapkan mendapat informasi/ data tentang perbedaan hasil belajar Hadits yang dilakukan dengan metode pembelajaran hypnoteaching yang dibandingkan dengan metode pembelajaran ekspositori.

Desain penelitian yang digunakan dalam penelitian ini adalah desain eksperimen dengan faktorial $2 \times 2$. Dalam penelitian ini variabel bebas pertama terdiri dari dua karakteristik yakni metode hypnoteaching dan metode ekspositori. Sedangkan pada variabel bebas kedua (variabel kontrol) terdiri dari dua karakteristik yakni gaya belajar Kinestetik dan gaya belajar Visual. Dan variabel terikatnya adalah hasil belajar Hadits. Desain penelitian dimaksud dapat digambarkan seperti Tabel 1 berikut

Tabel 1. Desain Penelitian untuk Pengujian Hipotesis

\begin{tabular}{|c|c|c|}
\hline Metode pembelajaran (A) & Hypnoteaching (A1) & Ekspositori (A2) \\
Gaya belajar (B) & & A2B1 \\
\hline Visual (B1) & A1B1 & A2B2 \\
\hline Kinestetik (B2) & A1B2 & \\
\hline
\end{tabular}


Untuk melakukan analisis data digunakan teknik analisis Deskriptif dan teknik analisis inferensial. Analisis statistik Deskriptif yaitu untuk menggambarkan data penelitian dengan membuat daftar distribusi frekuensi dan membuat histogram. Dan dari daftar frekuensi tersebut dihitung nilai rata-rata, simpangan baku, median, modus dan varian.

Analisis statistik Inferensial, untuk menguji hipotesis. Sebelum pengujian hipotesis dilakukan uji persyaratan yakni uji normalitas data penelitian dengan teknik Liliefors, kemudian dilanjutkan dengan uji homogenitas dengan menggunakan uji $\mathrm{F}$ dan Bartlett. Untuk uji hipotesis penelitian ini digunakan teknik ANAVA 2 x 2 (ANAVA dua jalur) dengan uji $\mathrm{F}$ dengan taraf signifikan $\alpha=0,05$.

Apabila dari hasil analisis Fhitung terdapat perbedaan rata-rata variabel terikat dari dua sampel sebagai akibat variabel bebas, maka analisis akan dilanjutkan dengan dengan uji Schefee

Untuk memberi arah dalam analisis data, maka hipotesis perlu dinyatakan dalam rumus statistik. Hipotesis diuji dengan menggunakan:

1. Uji normalitas . dilakukan dengan asumsi bahwa gejala yang diteliti dalam penelitian ini, metode pembelajaran pembelajaran, gaya belajar siswa dan hasil belajar siswa yang terpilih sebagai sampel, penyebarannya dalam populasi bersifat normal. Uji normalitas dilakukan dengan Uji Liliefors.

2. Uji homogenitas. Dilakukan dengan asumsi bahwa gejala dalam penelitian ini, yaitu metode pembelajaran pembelajaran dan hasil belajar sabagai sampel, penyebarannya dalam populasi bersifat homogen. Uji homogenitas dilakukan dengan Uji F dan $U j i$ Bartlett.

Adapun rumusan hipotesis statistik ini dinyatakan sebagai berikut :

Hipotesis $1 \quad$ : Ho $\quad: \mu_{\mathrm{A} 1}=\mu_{\mathrm{A} 2}$

$\mathrm{Ha} \quad: \mu_{\mathrm{A} 1}>\mu_{\mathrm{A} 2}$

Hipotesis $2 \quad:$ Ho $\quad: \mu_{\mathrm{B} 1}=\mu_{\mathrm{B} 2}$

$\mathrm{Ha} \quad: \mu_{\mathrm{B} 1}>\mu \mathrm{B}_{\mathrm{A} 2}$

Hipotesis $3 \quad$ : Ho $: \mathrm{A} \times \mathrm{B}=0$

$\mathrm{Ha} \quad: \mathrm{A} \times \mathrm{B} \neq 0$

Keterangan

$\mu_{\mathrm{A} 1} \quad$ : Rata-rata hasil belajar Hadits peserta didik yang dibelajarkan dengan metode pembelajaran hypnoteaching

$\mu_{\mathrm{A} 2}$ : Rata-rata hasil belajar Hadits peserta didik yang dibelajarkan dengan metode pembelajaran ekspositori

$\mu_{\mathrm{B} 1}$ : Rata-rata hasil belajar Hadits peserta didik yang memiliki gaya belajar visual

$\mu_{\mathrm{B} 2} \quad$ : Rata-rata hasil belajar Hadits peserta didik yang memiliki gaya belajar kinestetik

A x B: Interaksi antara metode pembelajaran dengan gaya belajar

\section{HASIL DAN PEMBAHASAN}

Hasil

Sebelum melakukan pengujian hipotesis terlebih dahulu menghitung total skor dan rata-rata skor tiap kelompok perlakuan menurut tabel ANAVA, yang selanjutnya dapat digunakan sebagai dasar keputusan statistik untuk pengujian hipotesis, dapat dilihat dalam tabel 2 berikut:

Tabel 2. Data Induk Penelitian

\begin{tabular}{|c|c|c|c|c|}
\hline \multirow{2}{*}{\multicolumn{2}{|c|}{ Gaya Belajar }} & \multicolumn{2}{|c|}{ Metode Pembelajaran } & \multirow{3}{*}{$\begin{array}{r}\text { Total } \\
33\end{array}$} \\
\hline & & \multirow{2}{*}{$\begin{array}{ll}\text { Hypnoteaching } \\
\end{array}$} & \multirow{2}{*}{$\begin{array}{r}\text { Ekspositori } \\
17\end{array}$} & \\
\hline \multirow{5}{*}{ Visual } & $\mathrm{n}$ & & & \\
\hline & $\sum X$ & 1317 & 1112 & 2429 \\
\hline & $\sum \mathrm{X}^{2}$ & 108571 & 73216 & 181787 \\
\hline & $\bar{X}$ & 82.51 & 72.50 & 77.5 \\
\hline & $\mathrm{S}^{2}$ & 11.029 & 29.88 & 40.91 \\
\hline \multirow{5}{*}{ Kinestetik } & $\mathrm{n}$ & 15 & 15 & 30 \\
\hline & $\sum X$ & 1036 & 1077 & 2113 \\
\hline & $\sum X^{2}$ & 71778 & 77521 & 149299 \\
\hline & $\dot{X}$ & 66.13 & 69.51 & 66.32 \\
\hline & $S^{2}$ & 16.06 & 13.73 & 29.80 \\
\hline \multirow{2}{*}{ TOTAL } & $\mathrm{n}$ & 31 & 32 & 63 \\
\hline & $\sum X$ & 2353 & 2189 & 4542 \\
\hline
\end{tabular}




\begin{tabular}{|c|r|r|r|}
$\sum \mathrm{X}^{2}$ & 180349 & 150737 & 331086 \\
\hline $\bar{X}$ & 75.69 & 68.61 & 72.15 \\
\hline $\mathrm{S}^{2}$ & 27.15 & 43.61 & 70.71 \\
\hline
\end{tabular}

Secara keseluruhan hasil perhitungan Anava untuk pengujian hipotesis dapat dilihat dalam Tabel 3 berikut :

Tabel 3. Rangkuman Hasil Perhitungan ANAVA Faktorial 2 x 2

\begin{tabular}{|l|r|r|r|r|r|l|}
\hline Sumber Variasi & \multicolumn{1}{l|}{ dk } & \multicolumn{1}{l|}{ JK } & \multicolumn{1}{l|}{ RJK } & F $_{\text {hitung }}$ & F $_{\text {tabel }}$ & Keterangan \\
\hline Metode Pembelajaran (A) & 1 & 885.00 & 885.00 & 49.23 & 4.08 & Signifikan \\
\hline Gaya belajar (B) & 1 & 158.18 & 158.18 & 8.80 & 4.08 & Signifikan \\
\hline Interaksi (AxB) & 1 & 1525.36 & 84.83 & 84.83 & 4.08 & Signifikan \\
\hline Antar Kelompok & 3 & 2568.54 & - & & & \\
\hline Galat & 59 & 1060.89 & 17.98 & & & \\
\hline TOTAL & 63 & & & & & \\
\hline
\end{tabular}

Pengujian hipotesis statistik untuk metode pembelajaran hypnoteaching dan metode pembelajaran ekspositori adalah sebagai berikut:

Pernyataan hipotesis statistik yang diuji adalah :

Ho : $\mu \mathrm{A}_{1}=\mu \mathrm{A}_{2}$

Berdasarkan hasil perhitungan data dapat diketahui bahwa siswa yang dibelajarkan dengan menggunakan metode pembelajaran hypnoteaching memperoleh nilai rata-rata 75,73, sedangkan hasil belajar Hadits siswa yang dibelajarkan dengan metode pembelajaran ekspositori memperoleh nilai rata-rata 67,00.

Hasil analisis varians untuk kedua pendekatan pembelajaran menunjukkan harga $F_{h}$ sebesar 49,22 lebih besar dari harga $F_{t}$ sebesar 4,08 pada taraf signifikan $\alpha=0,05$ sehingga $\mathrm{H}_{\mathrm{o}}$ ditolak dan Ha diterima pada taraf signifikan $\alpha=0,05$. Dengan demikian dapat disimpulkan bahwa kelompok siswa yang dibelajarkan dengan menggunakan metode pembelajaran hypnoteaching memperoleh hasil belajar Hadits lebih tinggi dari kelompok siswa yang dibelajarkan dengan metode pembelajaran ekspositori teruji kebenarannya.

Pengujian terhadap hipotesis statistik tentang gaya belajar visual dan gaya belajar kinestetik adalah sebagai berikut:

Pernyataan hipotesis statistik yang diuji adalah :

Ho : $\mu \mathrm{B}_{1}=\mu \mathrm{B}_{2}$

$\mathrm{Ha}: \mu \mathrm{B}_{1}>\mu \mathrm{B}_{2}$

Berdasarkan hasil perhitungan data dapat diketahui bahwa siswa yang menggunakan gaya belajar visual memperoleh nilai rata-rata 71,75 , sedangkan hasil belajar Hadits siswa yang memiliki gaya belajar kinestetik memperoleh nilai rata-rata 70,50.

Hasil analisis varians untuk kedua pendekatan gaya belajar menunjukkan harga $F_{h}$ sebesar 8,80 lebih besar dari harga $F_{t}$ sebesar 4,09 pada taraf signifikan $\alpha=0,05$ sehingga $H_{\circ}$ ditolak dan Ha pada taraf signifikan $\alpha=0,05$. Dengan demikian dapat disimpulkan bahwa lebih tinggi hasil belajar Hadits siswa yang memiliki gaya belajar visual dengan memiliki gaya belajar kinestetik teruji kebenarannya.

2. Interaksi Antara Metode Pembelajaran dan Gaya Selajar Terhadap Hasil Belajar Hadits Siswa adalah :

Pernyataan hipotesis statistik yang diuji

$$
\text { Ho : } \mathrm{A}><\mathrm{B}=0
$$

Ha : $\mathrm{A}><\mathrm{B} \neq 0$

Keterangan

Berdasarkan hasil pengujian hipotesis di atas diperoleh $F_{h}=84,83$ dan nilai kritik $F_{t}=$ 4,08 dengan $\mathrm{dk}(1,63)$ pada taraf $\alpha=0,05$. Hasil ini menunjukkan bahwa $F_{h}=84,83>F_{t}=4,09$ sehingga Ho ditolak dan Ha diterima pada taraf $\alpha=0,05$, dengan demikian hipotesis yang menyatakan bahwa terdapat interaksi antara penggunaan metode pembelajaran dan gaya belajar dalam memberikan pengaruh terhadap hasil belajar Hadits siswa teruji kebenarannya.

Karena ada interaksi antara metode pembelajaran dan gaya belajar dalam mempengaruhi hasil belajar Hadits siswa, maka perlu dilakukan uji lanjutan, untuk 
mengetahui rata-rata hasil belajar sampel mana yang berbeda. Untuk melihat bentuk interaksi antara metode pembelajaran dan gaya belajar dalam mempengaruhi hasil belajar Hadits siswa dilakukan uji lanjut dengan menggunakan Uji Scheffe. Hasil perhitungan menggunakan Uji Scheffe dapat dilihat dalam Tabel 4 berikut :

Tabel 4. Ringkasan Hasil Perhitungan Uji Scheffe

\begin{tabular}{|c|c|c|c|}
\hline No & Interaksi & Fhitung & $\mathrm{F}_{\text {tabel }}(\alpha=0,05)$ \\
\hline 1 & $\mu \mathrm{A}_{1} \mathrm{~B}_{1}$ dengan $\mu \mathrm{A}_{2} \mathrm{~B}_{1}$ & $8,96^{*}$ & 4,09 \\
\hline 2 & $\mu \mathrm{A}_{1} \mathrm{~B}_{1}$ dengan $\mu \mathrm{A}_{2} \mathrm{~B}_{2}$ & $6,16^{*}$ & 4,09 \\
\hline 3 & $\mu \mathrm{A}_{1} \mathrm{~B}_{1}$ dengan $\mu \mathrm{A}_{1} \mathrm{~B}_{2}$ & $4,87^{*}$ & 4,09 \\
\hline 4 & $\mu \mathrm{A}_{1} \mathrm{~B}_{2}$ dengan $\mu \mathrm{A}_{2} \mathrm{~B}_{1}$ & $1,71^{* *}$ & 4,09 \\
\hline 5 & $\mu \mathrm{A}_{1} \mathrm{~B}_{2}$ dengan $\mu \mathrm{A}_{2} \mathrm{~B}_{2}$ & $3,01^{* *}$ & 4,09 \\
\hline 6 & $\mu \mathrm{A}_{2} \mathrm{~B}_{2}$ dengan $\mu \mathrm{A}_{2} \mathrm{~B}_{1}$ & $1,24^{* *}$ & 4,09 \\
\hline
\end{tabular}

Keterangan : $*$ signifikan $* *=$ tidak signifikan

Untuk melihat dengan jelas model Anava yang menunjukkan adanya interaksi antara penggunaan metode pembelajaran dan gaya belajar dalam mempengaruhi hasil belajar siswa dapat ditunjukkan melalui Gambar 1 berikut:

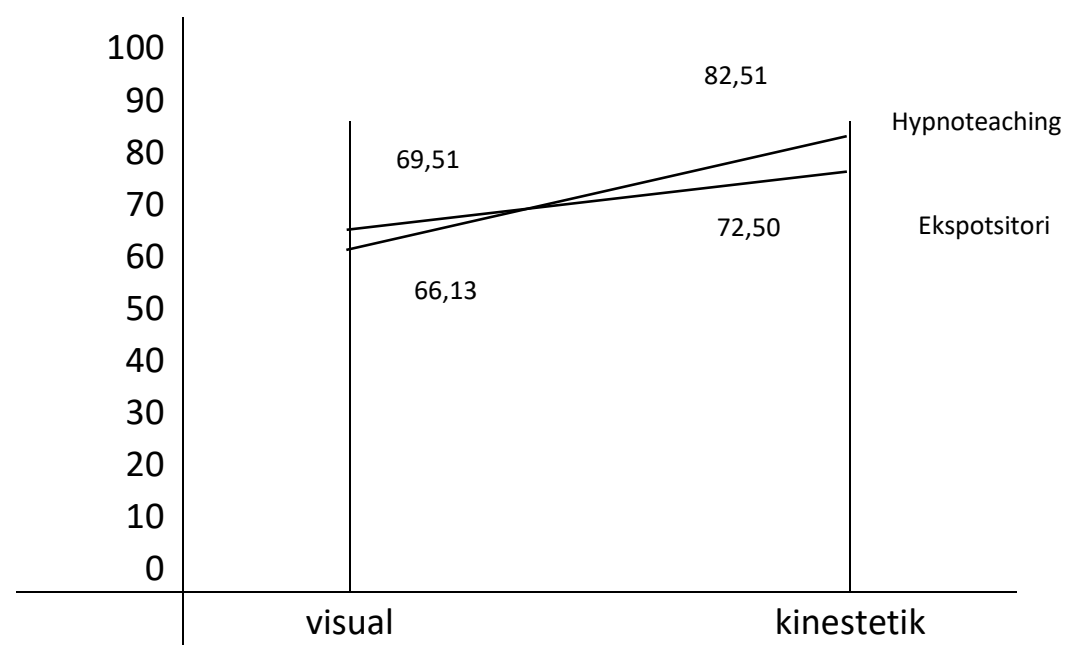

Gambar 1. Pola Garis Interaksi antara Strategi Pembelajaran dan Gaya Belajar Terhadap Hasil Belajar Siswa

\section{Pembahasan}

Data yang diperoleh dalam penelitian ini ternyata membuktikan bahwa metode pembelajaran yang digunakan cukup signifikan untuk membedakan hasil belajar siswa. Dari hasil analisis data diperoleh bahwa secara ratarata hasil belajar Hadits dengan menggunakan metode pembelajaran hypnoteaching lebih tinggi dari pada menggunakan metode pembelajaran ekspositori. Hal ini berindikasi bahwa metode pembelajaran hypnoteaching lebih baik dalam meningkatkan pemahaman siswa terhadap materi pelajaran Hadits. Dari hasil ini menunjukkan bahwa untuk mengajarkan materi Hadits lebih baik menggunakan metode pembelajaran hypnoteaching dibandingkan metode pembelajaran ekspositori.
Mata pelajaran Hadits merupakan mata pelajaran yang berkaitan dengan tuntunan kehidupan, karena di dalam pelajaran Hadits tidak hanya diajarkan ubudiyyah atau ibadah dan menghambakan diri kepada Sang Pencipta, tapi juga berisi ajaran-ajaran budi pekerti dan sopan santun kepada diri sendiri dan sekitar. Ajaran-ajaran tersebut tentu harus diterapkan dalam kehidupan sehari-hari. Bagaimana seorang guru bisa menanamkan ajaran-ajaran tersebut tidak hanya ke dalam otaknya, tapi juga ke dalam hatinya tentu tidaklah mudah. Dibutuhkan keahlian guru untuk memilih metode pembelajaran yang sesuai sehingga apa yang diajarkannya bermakna dan berkesan bagi peserta didik dan menjadi tuntunan dalam hidupnya. 
Metode pembelajaran yang digunakan dalam menyampaikan pelajaran Hadits harus mempertimbangkan karakteristik pelajaran seperti yang telah dijelaskan sebelumnya.. Meskipun demikian, Hadits juga perlu dijelaskan oleh guru secara teoritis dengan menggunakan metode ceramah. Namun, guru harus kreatif untuk memadukan metode ceramah dengan metode lain yang mendukung dalam menciptakan suasana menyenangkan sehingga ajaran-ajaran Nabi Muhammad SAW dalam Hadits yang dianggap sulit dapat diserap siswa dengan mudah, apalagi Hadits Nabi Muhammad SAW berbahasa asing, yaitu bahasa Arab.

Selain sifat dari materi pelajaran, salah satu dasar pemikiran lain yang digunakan oleh guru sebagai pertimbangan dalam merancang metode pembelajaran adalah karakteristik siswa, karakteristik siswa merupakan salah satu hal yang perlu diidentifikasi oleh guru untuk digunakan sebagai petunjuk dalam mengembangkan program pembelajaran. Setiap siswa memiliki potensi dan karakteristik yang berbeda-beda. Seorang guru harus berusaha mengakomodir potensi siswa secara maksimal dalam metode pembelajaran yang diterapkan di kelas. Karakteristik siswa seperti motivasi, minat, bakat, kecerdasan, gaya belajar, kepribadian, emosi, perasaan, pikiran, dan metakognisi perlu dipertimbangkan dan diintegrasikan dalam metode pembelajaran yang dirancang.

Pelajaraan Hadits tidak hanya berhubungan dengan hafalan teori tetapi lebih mementingkan perbuatan sehari-hari. Dalam mempelajari Hadits sangat membutuhkan pemahaman siswa. Dalam memahami Hadits ini, bukan sekedar menerima apa yang telah diberikan oleh guru. Siswa harus mampu mengaitkan apa yang dipelajari dengan kehidupan sehari-hari sehingga pelajaran Hadits akan lebih mudah dipahami.

Dalam mempelajari Hadits sangat dibutuhkan variasi aktivitas kelas sehingga tidak membuat siswa bosan. Dengan beragam aktivitas siswa merasa nyaman dan membangun pikiran positif sehingga tidak menganggap Hadits sebagai pelajaran yang sulit. Aktivitas yang beragam dalam metode hypnoteaching seperti, yelling, ajarkan dan puji serta pertanyaan ajaib akan meningkatkan keterlibatan siswa dalam proses pembelajaran dan menjaga agar siswa tetap berkonsentrasi mengikuti pelajaran.
Dari segi metode mengajar yang digunakan, metode pembelajaran hypnoteaching melibatkan bermacam metode untuk mengakomodasikan berbagai tipe gaya belajar siswa dan teknik belajar untuk memudahkan siswa belajar. Ketika mengajar guru tidak hanya menggunakan metode ceramah untuk menyampaikan informasi yang artinya hanya mempertimbangkan gaya belajar siswa yang auditori tetapi juga mempertimbangkan siswa dengan gaya belajar visual dan kinestetik, sehingga selain ceramah guru juga menggunakan gambar-gambar, model, warna-warna, permainan, role playing dan sebagainya untuk mengakomodasikan semua gaya belajar siswa. Sehingga belajar menjadi lebih menyenangkan dan setiap siswa diberi kesempatan yang untuk dapat menyerap informasi sesuai dengan gaya belajarnya masing-masing.

Hasil penelitian membuktikan bahwa gaya belajar siswa cukup signifikan untuk membedakan hasil belajar Hadits. Gaya belajar siswa dalam penelitian ini dikategorikan atas dua kategori yaitu gaya belajar visual dan gaya belajar kinestetik. Dari hasil analisis data diperoleh bahwa secara rata-rata hasil belajar Hadits siswa yang memiliki gaya belajar visual lebih baik dari pada siswa yang memiliki gaya belajar kinestetik. Hal ini berindikasi bahwa siswa yang mempunyai gaya belajar visual secara rata-rata mempunyai hasil belajar Hadits yang lebih baik dibandingkan siswa yang memiliki gaya belajar yang rendah. Dengan demikian siswa yang mempunyai gaya belajar yang tinggi lebih memahami pelajaran Hadits dibandingkan siswa yang mempunyai gaya belajar yang rendah.

Sedangkan Kinestetik akan lebih mudah belajar dengan melibatkan gerakan-gerakan fisik. Di samping itu "mereka suka membuat model, belajar melalui manipulasi, dan praktik, cenderung menyukai tantangan, dengan gerakan-gerakan fisiknya siswa yang memiliki gaya belajar ini suka bereksperimen sendiri. Biasanya kelincahan otak/berpikir anak/siswa yang memiliki gaya belajar kinestetik relatif sama dengan kelincahan gerakan-gerakan tubuhnya. Gaya belajar ini mengakses segala jenis gerak, aktivitas tubuh, emosi, koordinasi. Siswa yang memiliki gaya belajar visual lebih mudah diajarkan melalui pengamatan, penemuan, diskusi dan tanya jawab. Dalam pembelajaran siswa di Hadits ini dapat mengerti dan memahami materi yang diajarkan melalui 
alat peraga sebagai objek atau gambaran dari materi yang dipelajari dengan fokus. Sedangkan siswa yang memiliki gaya belajar Kinestetik lebih mudah mengerti dan memahami informasi atau materi pelajaran melalui keterlibatan gerakan. Siswa ini sulit sekali untuk fokus terhadap suatu materi sehingga sebaiknya dalam pembelajaran mereka pengajar/guru dapat mengasosiasikan materi pelajaran dengan melibatkan gerakan-gerakan fisik si anak/siswa.

Hasil analisis diperoleh, terdapat perbedaan interaksi metode pembelajaran dan gaya belajar siswa dalam mempengaruhi hasil belajar Hadits siswa. Secara rata-rata kelompok siswa yang memiliki gaya belajar visual dan dibelajarkan dengan menggunakan metode pembelajaran hypnoteaching mempunyai hasil belajar Hadits yang lebih baik dibandingkan dengan menggunakan metode pembelajaran Ekspositori. Kemudian secara rata-rata hasil belajar Hadits kelompok siswa yang memiliki gaya belajar kinestetik dan dibelajarkan dengan metode pembelajaran hypnoteaching tidak lebih baik (lebih rendah) dibandingkan dengan kelompok siswa yang memiliki gaya belajar kinestetik tapi dibelajarkan dengan menggunakan metode pembelajaran ekspositori.

Dengan kata lain bagi kelompok siswa yang memiliki gaya belajar kinestetik lebih baik menggunakan metode pembelajaran ekspositori dibandingkan dengan menggunakan metode pembelajaran berbasis hypnoteaching, walaupun perbedaan hasil belajar Hadits tersebut tidak signifikan. Jadi dalam hal ini metode pembelajaran dan gaya belajar siswa cukup signifikan untuk mempengaruhi hasil belajar Hadits siswa.

Bagi siswa yang memiliki gaya belajar visual lebih mudah dibelajarkan melalui pengamatan, penemuan, diskusi dan tanya jawab. Dengan metode hypnoteaching yang memperkenankan siswa-siswanya menemukan sendiri suatu konsep, teori aturan, atau pemahaman melalui contoh-contoh yang ia jumpai dalam pembelajaran adalah cocok dan akan memancing perkembangan otaknya secara maksimal. Melalui metode hypnoteaching membawa siswa lebih kreatif dan kritis serta semangat, sehingga hasil belajarnya tinggi. Sedangkan gaya belajar Kinestetik, yang suka melibatkan gerakan-gerakan fisik dalam kegiatan belajarnya jika dibelajarkan dengan metode hypnoteaching maka hasil belajarnya akan sedikit meningkat. Namun, jika siswa yang memiliki gaya belajar kinestetik ini diajar dengan metode ekspositori, mereka akan lebih fokus, terarah dalam belajar. Sehingga minat belajar pun tumbuh. Akibatnya hasil belajarnya akan semakin baik.

Berdasarkan hasil belajar pendidikan Hadits siswa secara keseluruhan, terjadi peningkatan hasil belajar sebelum perlakuan dan sesudah perlakuan, khususnya pada perlakuan metode pembelajaran hypnoteaching. Sedangkan pada kelas metode pembelajaran ekspositori, meskipun terjadi peningkatan hasil belajar, namun peningkatan rata-rata hasil belajar ini lebih baik dibandingkan dengan nilai rata-rata hasil belajaran yang selama ini dilaksanakan di lokasi penelitian.

\section{PENUTUP}

Simpulan hasil penelitian ini adalah sebagai berikut:

1. Hasil belajar Hadits siswa yang diajar dengan metode pembelajaran hypnoteaching lebih tinggi dibandingkan siswa yang diajar dengan metode pembelajaran ekspositori.

2. Hasil belajar Hadits siswa yang memiliki gaya belajar visual lebih tinggi dibandingkan dengan hasil belajar Hadits siswa yang memiliki gaya belajar kinestetik.

3. Terdapat interaksi antara metode pembelajaran dan gaya belajar dalam mempengaruhi hasil belajar Hadits siswa. Siswa yang memiliki gaya belajar visual memiliki hasil belajar lebih tinggi dibandingkan dengan siswa yang memiliki gaya belajar kinestetik yang diajar dengan metode pembelajaran hypnoteaching. Sebaliknya, hasil belajar Hadits siswa yang memiliki gaya belajar kinestetik memiliki hasil belajar lebih tinggi dibanding dengan siswa yang memiliki gaya belajar visual yang diajar dengan metode pembelajaran ekspositori.

\section{DAFTAR PUSTAKA}

Akbar, Ali. 2013. Hypnoteaching: Revolusi Gaya Mengajar Untuk Melejitkan Prestasi Siswa, Jogjakarta: Ar-Ruzz Media.

Arifin dan Setiyawan. 2012. Pengembangan Pembelajaran Aktif dengan ICT, Jogjakarta: Skripta Media Creative.

Arikunto, Suharsimi. 2006. Prosedur Penelitian Suatu Pendekatan Praktek, Jakarta: Rineka Cipta.

Asri Budiningsih, C. 2005. Belajar dan Pembelajaran. : Jakarta: Rineka Cipta. 
Chatib, Munif. 2009. Sekolahnya Manusia: Sekolah Berbasis Multiple Intelligences di Indonesia. Bandung : PT Mizan Pustaka

Dimyati dan Mudjiono. 2009. Belajar dan Pembelajaran, Jakarta: Rineka Cipta.

De Porter, Bobbi dan Mike Hernachi. terjemahan Alwiyah Abdurrahman. 2000. Quantum Learning: Membiasakan Belajar Nyaman dan Menyenangkan. Bandung: Kaifa.

De Porter, Bobbi dan Mike Hernachi. terjemahan Nilandari. 2000. Quantum Teaching: Mempraktekkan Quantum Learning di ruang-ruang kelas. Bandung: Kaifa.

Dick and Carey. 2005. The Systematic Design of Instruction. New York: Wesley Education.

Emzir. 2008. Metodologi Penelitian Pendidikan Kuantitatif \& Kualitatif. Jakarta: Raja Grafindo Persada.

Fananie, Zainuddin. 2011. Pedomana Pendidikan Modern, Solo: Tinta Medina.

Gunawan, W, Adi. 2007. Genius Learning Strategy. Jakarta, Gramedia.

Hadi, Sutrisno. 2000.Bimbingan Menulis Skripsi \& Thesis, Jogjakarta: Andi.

Hamalik, Oemar. 2005. Proses Belajar Mengajar. Jakarta: Bumi Aksara.

Hafid, Anwar. 2013. Konsep Dasar Ilmu Pendidikan, Bandung: Alfabeta.

Komalasari, Kokom. 2010. Pembelajaran Kontekstual, Konsep dan Aplikasi. Bandung: Refika Aditama.

Miarso, Yusufhadi. 2007. Menyemai Benih Teknologi Pendidikan. Jakarta: Kencana Prenada Media Group.

Mosston, Muska. 1972. Teaching From Command to Discovery. Wadsworth Publishing Company. Inc,Belmont. California

Muhibbinsyah. 2010. Psikologi Pendidikan Dengan Pendekatan Baru. Bandung : Remaja Rosda Karya.

Mukhtar dan Iskandar. 2012. Desain Pembelajaran Berbasis TIK, Jakarta: Referensi.
Nurseha, Qosim. 2012. Lezatnya Menuntut Ilmu, Depok: Indie Publishing.

Rusman. 2010. Model-model Pembelajaran, Jakarta: RajaGrafindo Persada.

Rusman dan Kurniawan. 2011. Pembelajaran Berbasis Teknologi Informasi dan Komunikasi, Jakarta: RajaGrafindo Persada.

Sanjaya, Wina. 2006. Strategi Pembelajaran Berorientasi Standar Proses Pendidikan. Jakarta : Kencana.

Sanjaya, Wina. 2008. Perencanaan dan Desain Sistem Pembelajaran. Jakarta: Kencana.

Sagala, Syaiful. 2003. Konsep dan Makna Pembelajaran, Bandung: Alfabeta.

Slameto. 2003. Belajar dan Faktor-Faktor yang Mempengaruhinya. Jakarta: Rineka Cipta.

Sudjana, N. 2005. Metode Statistika. Bandung: Tarsito.

Sugiyono, 2009. Metode Penelitian Pendidikan Pendekatan Kuantitatif, Kualitatif, dan R \& D.Bandung : Alfabeta.

Sukardi. 2003. Metode Penelitian Pendidikan. Jakarta : Bumi Aksara.

Sukiman. 2012. Pengembangan Sistem Evaluasi, Jogjakarta: Insan Madani.

Sutrisno. 2012. Kreatif Mengembangkan Aktivitas Pembelajaran Berbasis TIK, Jakarta: Referensi.

Suyatno, 2009. Menjelajah Pembelajaran Inovatif. Surabaya : Masmedia Buana Pustaka

Suryosubroto, B. 2009. Proses Belajar Mengajar di Sekolah. Jakarta: Rineka Cipta.

Warsita, Bambang. 2008. Teknologi Pembelajaran, Landasan dan Aplikasinya, Jakarta: Rineka Cipta.

Yusuf Tayibnapis, Farida.2008. Evaluasi Program dan Instrumen Evaluasi untuk Program Pendidikan dan Penelitian, Jakarta: Rineka Cipta.

Yustisia,2012. Hypnoteaching: Seni Ajar Mengeksplorasi Otak Peserta Didik, Jogjakarta: Ar-Ruzz Media. 